\title{
How can planning for sustainability improve Costa de Caparica's nightlife?
}

\section{Diana Neves Almeida \& João Mota-Guedes Fumega}

To cite this article: Diana Neves Almeida \& João Mota-Guedes Fumega (2012) How can planning for sustainability improve Costa de Caparica's nightlife?, International Journal of Urban Sustainable Development, 4:1, 111-123, DOI: 10.1080/19463138.2012.667411

To link to this article: https://doi.org/10.1080/19463138.2012.667411

\section{曲 Published online: 28 Mar 2012.}

Submit your article to this journal

Џ Article views: 96 


\title{
How can planning for sustainability improve Costa de Caparica's nightlife?
}

\author{
Diana Neves Almeida* and João Mota-Guedes Fumega \\ Centre for Geographical Studies, Institute of Geography and Spatial Planning, University of Lisbon, Ed.Fac.Letras, \\ Alameda da Universidade, Lisbon 1600-214, Portugal
}

(Received 19 April 2011; final version received 27 January 2012)

In the twentieth century, several transformations occurred in the way society used and perceived urban lighting. This allowed the growth of leisure and other activities related to free time and culture into the night period. Night gained an increasing importance among urban policies and therefore required to be framed within these complex urban contexts as well as other planning processes. This article addresses the Polis Program and its contribution to the improvement of Costa de Caparica's nightlife. It aims to analyse the urban renewal intervention of the Polis Program at Costa de Caparica in terms of night economy and sustainability concerns, in light of Egan's sustainable communities' components. The argument is that the planning of night can contribute to the construction of a sustainable community. The main conclusions focus on the importance that should have been given to governance, public participation and equity components of Egan's wheel along the implementation of the programme, as well as in planning processes broadly, towards achieving a sustainable nightlife.

Keywords: nightlife; sustainability; planning; Costa de Caparica; Polis Program; governance

\section{Introduction}

Social and cultural changes of recent decades have increased the importance of night as a spatial and time concept essential to urban areas. Among the changing drivers, some transformations occurred in modern societies: the liberalization of social practices; demographic changes; increase of single people without limitations of time; the coming out of new highly standardized urban life patterns. This range of circumstances has attenuated the day-night sequence, at the same time that different rhythms are gaining a new importance. In addition, leisure and cultural practices related to free time have gained a new projection in the social sphere free time has emerged as an important period of self-evaluation. These transformations are related to technological innovations in urban lighting, which has allowed the take up of economic, cultural or political activities into the night. Furthermore, there is a growing democratization of leisure as a group of night experiences, contributing to the development of new segments of economic activities that only exist in the night-time period (Alves 2010).

In this context, planning the urban night has countless advantages, not only in the programming of activities and public space security issues but also in what concerns sustainability of energy consumption and equity in access (Hollands and Chatterton 2003; Espinasse and Buhagiar 2004; Alves 2007).

This article addresses the Polis Program and its contribution to the improvement of Costa de Caparica's nightlife. It aims to analyse the urban

*Corresponding author. Email: diana-almeida@campus.ul.pt 
renewal intervention of the Polis Program at Costa de Caparica in terms of night economy and sustainability concerns, in light of Egan's sustainable communities' components. The argument is that planning of night uses can contribute to the construction of a sustainable community. In addition, Polis Program should have given a better contribution in this sense, regarding mainly the inclusion of governance and participation in the planning process.

The Polis Program results directly from a set of national assumptions of a general urban disorder (Baptista 2008), which then was applied to different small- and medium-sized cities requiring urban reorganization, environmental quality, accessibilities improvement and also urban uses and design enhancement. Furthermore, the Polis Program reflects a series of national decisions based on a top-down planning model, neglecting governance, equity and public participation components.

Failures found in Costa de Caparica's Polis Program analysis, concerning the irrelevance assigned to night uses, are restricted to this particular case. However, the absence of community's consultation and participation in the planning process and the post-plan information campaigns for key stakeholders are common to other Polis Programs.

\section{Night planning towards more sustainable communities}

Urban lighting had appeared by the year 1900, with the main function of beautifying and redecorating monuments, places and spaces (Narboni 2003). Still, night continued to represent a barrier towards day, assumed as the stage of all human activities. This dichotomy separated day and night very clearly, in which night was associated with the unknown, provoking fears, mystery, curiosity and contradiction (Gwiazdzinski 2005). All these uses and perceptions were slowly changed due to the spreading of artificial lighting, first associated with cities and also in rural areas, but mainly after the Second World War. Only decades later some less developed countries started to experience artificial lighting.

The spread of public illumination changed people's habits forever. Economic activities have taken advantage of artificial light, seeking greater efficiency and increasing work productivity, by extending the number of hours worked and dissolving the natural seasonal variations of light. All types of professional activities could enter deeper in the night period. Not only economic activities have undergone significant processes of change but also social and cultural practices have been transported, transformed and created in the night period. Leisure is a fundamental element in night planning. Incorporating urban lighting in planning considerations establishes the guidelines for design, orientation and efficiency of illumination projects. It generates urban life quality in terms of security, minimizing environmental risks and constituting an opportunity to enjoy the night sky (Instituto de Astrofisica de Canarias 1992). Light can be an instrument of (1) transforming and constructing new landscapes, (2) upgrading spaces and creating more suitable environments, (3) illuminating most remarkable built heritage, (4) highlighting details and materials and (5) livening public spaces by creating a functional day use and by promoting a night use of parks and gardens (Narboni 2003; Alves 2009).

The most common approach in the research done on night planning is related to light and security. However, there are a set of authors who analyse the night issue in a varied number of forms related with the time use perspective, cultural dimension of night, leisure activities, night economy and others. In this context, it is important to distinguish some of the main authors' perspectives on night studies. French authors such as Cauquelin (1977), Deleuil (1994), Ascher (1997), Paquot (2000), Gwiazdzinski (2003, 2005), Espinasse and Buhagiar (2004) and Espinasse et al. (2005) traditionally focus on the theme of night liveability and an experiences perspective. These authors tend to highlight the urban landscapes and their transformations, as well as the role of urban lighting design and planning as a way to differentiate and enhance 
public spaces. The other perspectives come mostly from English authors, with an approach to the night more related with the policies that regulate public space at night (Talbot 2007; Helms 2008; Pain and Smith 2008). These analyses focus essentially on the night economy as a starting point for solving problems such as alcoholism and crime, which tend to have a special incidence in the United Kingdom. Allied to the issue of urban night planning, there are also police regulation and security issues that reflect spatially segregated night uses.

Regarding the article's objective, planning issues have a direct application to the night's space-time dimension, mainly because these are neglected by planners and decision-makers, who usually plan for the day period. Both the dynamic night economy and the way people use public spaces affect their spatial construction, their relation with others and their integration in the community. For these reasons, it is important to contextualize night planning in a matrix that focuses the local scale through a point of view that enhances sustainability. Thus, some definitions are given to the concept of sustainable communities. The Geographical Association and Academy for Sustainable Communities defines sustainable communities as

[...] the places where people want to live and work, now and in the future. They meet the diverse needs of existing and future residents, are sensitive to their environment, and contribute to a high quality of life. They are safe and inclusive, well planned, built and run, and offer equality of opportunity and good services for all.

Egan (2004b), in the skills for sustainable communities report, presented the following definition:

Sustainable communities meet the diverse needs of existing and future residents, their children and other users, contribute to a high quality of life and provide opportunity and choice. They achieve this in ways that make effective use of natural resources, enhance the environment, promote social cohesion and inclusion and strengthen economic prosperity.
Finally, Roseland (2005) stresses the quality of life as the central goal of sustainable communities that "[...] seeks a better quality of life for all its residents while maintaining nature's ability to function over time by minimizing waste, preventing pollution, promoting efficiency and developing local resources to revitalize the local economy".

It is crucial to understand the concept of sustainable community and to define community as it is perceived in this concept. Community, in terms of sustainable communities' development, is regarded as an asset or capital that is created by spending time and effort in transformation and transaction activities (Ostrom 1993, quoted by Roseland 2005). The perspective of community capital includes natural, physical, economic, human, social and cultural forms of capital. The natural capital can be understood as the stock of natural assets that yields a flow of valuable goods and services into the future and can be divided into non-renewable resources, the finite capacity of natural systems to produce "renewable resources" and the capacity of natural systems to absorb our emissions and pollutants without side effects. The physical capital is the stock of material resources such as equipment, buildings, machinery and other infrastructure that can be used to produce a flow of future income. Economic capital is related to the ways that resources are allocated and people make decisions about their material life. It is important to strengthen the economic capital to make more use of less, maximizing the resources; making things ourselves; making something new and developing community financial institutions. Human capital comprehends health, education, skills, knowledge, leadership and access to services. It needs continual maintenance by investments through the human lifetime (Ostrom 1993, quoted by Roseland 2005). Social capital constitutes the essence that joins a community into a united group. It has an informal aspect related to social networks and a more formal aspect related to social development programmes. Social cohesiveness and civicness are strongly associated with social networks and participation in society, 
including the governance processes through which decisions are made (Roseland 2005). Two important characteristics make social capital differ from the physical: first, social capital does not wear upon being used more and more, and second, if it is not used it deteriorates at a relatively rapid rate. Finally, cultural capital is the product of shared experience through traditions, customs, values, heritage, identity and history.

Egan (2004a), in the report "The Egan review: skills for sustainable communities", identifies eight components that help to define and to apply the concept of sustainable communities (see Figure 1, Egan's wheel (2004c)).

They must be addressed as a group in order to respond adequately to the problems that communities face nowadays, and a common sub-component underlines them all: these communities must be of high quality, well run, connected, well served, fair for everyone, thriving, well designed, maintained, safe, adaptable, environmentally and cost effectively provided (Egan 2004b). The components

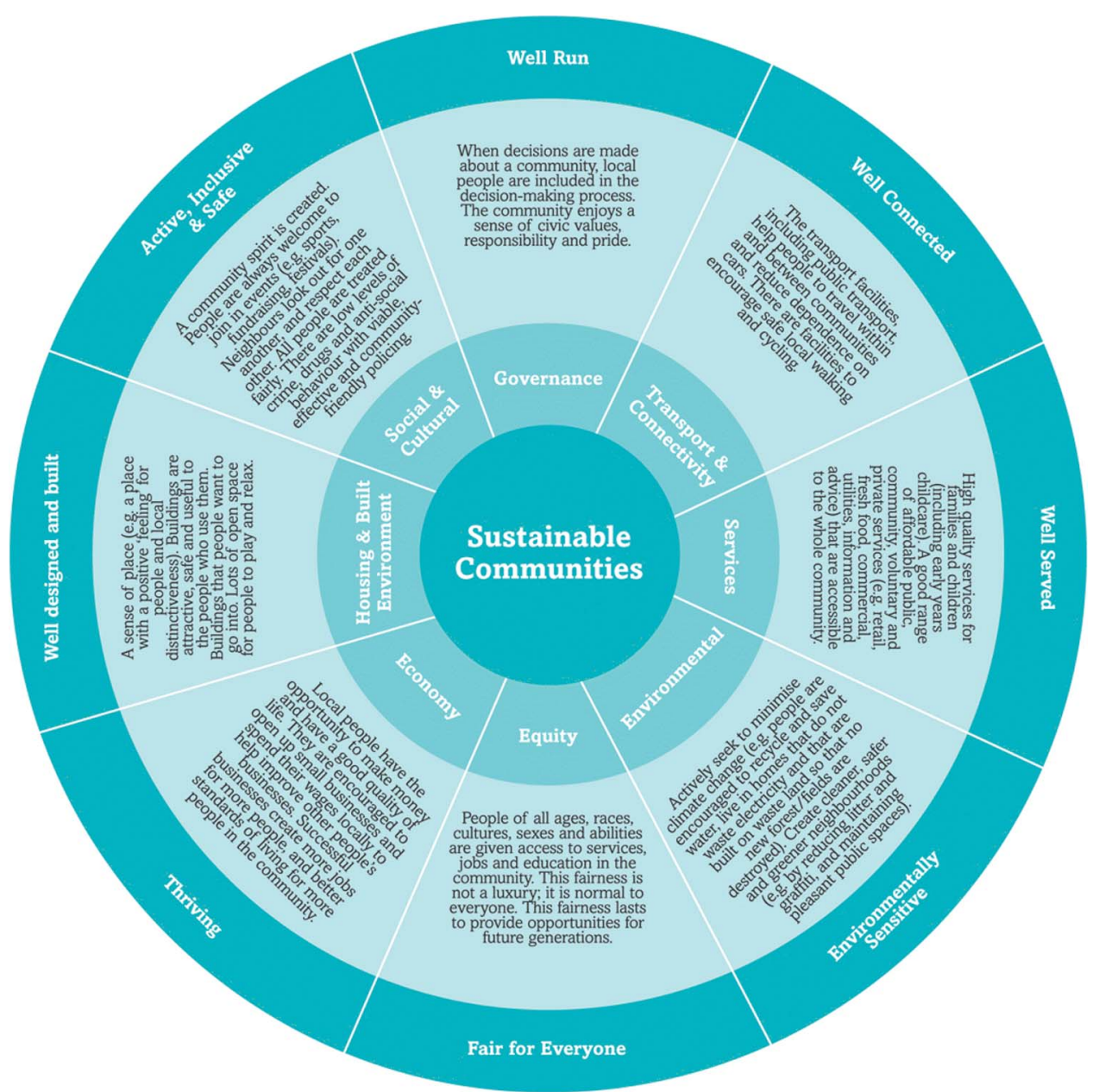

Figure 1. Egan's wheel: sustainable communities' components.

Source: http://www.geography.org.uk/projects/buildingsustainablecommunities/onlinecpdunit/stimulus/activity1/. 
are governance, transport and connectivity, services, environment, economy, housing and built environment, society and culture and equity, which function like guidelines to assess how to plan towards the promotion of the sustainability of a community. A community takes many years to accomplish, because the construction of social capital is something that cannot be created by planning without the complete involvement of the population. With the promotion of an inclusive participatory process, planning could function as a lever of the intrinsic qualities of a community, and in this sense Egan's eight components can provide a good answer because they reflect everything that a community should be, and every single one of them can have a straight relation to night economy, activities and night fruition as will be discussed under "Planning for sustainability in the context of Polis Program proposals".

\section{Costa de Caparica's nightlife and Polis Program framework}

Costa de Caparica is a small parish from Almada municipality in the heart of the Metropolitan Area of Lisbon (MAL), which is the main urban region in Portugal. It faces the Atlantic Ocean in its entire coast, providing regular beach uses not only for its residents but also for, and with a large representativeness of, other MAL residents and visitors (and tourists in a seasonal basis). Until the twentieth century, Costa de Caparica represented a group of fishing companies, carrying out traditional activities that occupied small urban nuclei. The shifting point occurred due to the construction of the bridge over the Tagus River (Ponte 25 de Abril), in 1966, which came to change the relationships between the south shore and the capital, and from which Costa de Caparica has benefited (Couto 2000 in Polis Program 2003). This fact allowed the intensification of the transportation flows, the population growth and the affirmation of this territory as a recreational and summer destiny in the context of the MAL due to its proximity to large beach areas. The explosive growth had its origins in a specific political and economic period of Portugal, resulting from the end of the imperial colonies in Africa, in 1974, from where the main part of the population returned. Almada municipality experienced a $51.3 \%$ increase of population, when Lisbon, by contrast, slowly lost population since 1981. Costa de Caparica has suffered in this period an important and drastic evolution from a small urban centre to a medium-sized urban centre within only a decade, an explosive growth which had in its origin the construction of an impressive number of clandestine houses. The most important economic activities are construction, retail, tourism, restaurants and accommodation services. They also register the highest employment rates: $18.5 \%$ of Costa de Caparica's residents work on services related to retail and sales and almost $16 \%$ in the restaurants and accommodation economic sector (Instituto Nacional de Estadistica 2001). Towards this distribution Costa de Caparica developed an important nucleus of tourism and leisure, mainly night economic activities, for example, restaurants, bars, discos and other night parties that usually blend music in the beach.

Like Costa de Caparica, many other smalland medium-sized cities in Portugal faced serious urban, mobility and environmental problems, which Baptista (2008) recalls as consequences of the "disorderly country". The author relies on two main aspects to affirm that the country is in disorder; the first one is based on political agendas supported by democratization principles, equity, environmental protection and decentralization of power. These particular transformations are associated with the end of a dictatorial political regime (1974), which reflected in the society economy and cultural spheres and with the entry of Portugal in the European Union in 1986. The second reason for the disorderly country focuses on the polarization of the urban structure. It is organized in turn of two metropolitan areas (Lisboa and Porto) and marked by a clear growth throughout the coastline of the main medium-sized cities, concentrating people and employment (Baptista 2008). The unplanned urban growth caused a discrepancy between public spaces, infrastructures 
and the actual urban fabric. Baptista (2008) also refers to the lack of commitment to environmental quality in urban areas, uncontrolled parking, traffic congestion and carless city centres as the reflection of poor policy options, which have missed a shared responsibility of governance and public participation in the planning processes (cf. "Egan's wheel" 2004c).

The Portuguese Government created the Polis Program to tackle this situation in the year 2000 (Law No. 26/2000). Environmental quality problems, lack of public spaces, traffic congestion and the emptiness of historical centres are the foremost foci of the programme. The main objective is to "improve the quality of life in cities through interventions in the urban and environmental sectors, improving the attractiveness and competitiveness of the urban centres that have a relevant role in the structure of the national urban system" (Law No. 26/2000). Polis initiative, which started with 18 cities, has now been applied to 28 cities of large dimensions and another 12 of small dimensions (total 40 cities). Ribeiro (1999) identified uncontrolled urban growth as the most common problem among Portuguese cities. Services rather than housing started to take part in the landscape of the old historical centres. Higher housing prices also kept people away from the city centres, stripping them of their old residential functions. These facts allowed an accelerated process of heritage degradation, being also associated with the lack of market incentives towards urban rehabilitation. Suburban growth was uncontrolled, revealing a disabled infrastructure and social systems allied to a poor urban liveability, long commuting journeys and lack of green public spaces, caused by a compact construction based on housing speculation.

Facing profound territorial problems, Polis Program interventions look forward to provide cities and urban centres new centralities and better quality of life. Their poor architecture and a weak urban environmental quality characterize the chaotic urban organization, stimulated in the last 10 years by secondary residences and camping that sprawled through the waterfront, creating a parallel barrier along the beach. In this specific case, the camping activity (mainly caravans) constitutes a type of permanent residence, apart from their holiday or weekend use. These represent a large stress to the environment, for example, in the water quality due to sewage discharges. Despite its housing functions, Costa de Caparica developed powerful attractions based on tourism and leisure, having $70 \%$ of seasonal dwellings in 1991, decreasing about $7 \%$ in 2001. Tourism and leisure of Costa de Caparica are mainly represented by two main driving forces: (1) occasional visits from the whole MAL - this kind of tourism is connected to leisure demand, focused specifically in beach pursuit; (2) holiday or weekend demand - this demand relates to both leisure and tourism needs but it is also focused mainly on a long-term beach pursuit.

The main urban problems identified in Costa de Caparica, in which Polis Program needed to intervene, were poor environment quality, bad housing conditions (shanty and rudimentary housing), lack of urban organization, limited transportation and accesses, lack of architectural quality, very few green spaces, bad quality accesses to the urban beaches, inadequate parking and waterfront's promenade in poor conditions. The work began at the end of 2006 and ended in April 2009, restructuring the whole village of Costa de Caparica.

Costa de Caparica's Polis Program considered eight anchor projects: waterfront regeneration, urban beach redesign, urban form, rural areas, camping park relocation, accessibility and transport. It consisted of seven detailed plans (PP); one for each specific area: urban beaches (PP1); urban gardens (PP2); Campo da Bola shanty neighbourhood (PP3); urban and rural west front (PP4); transition beaches (PP5); equipped beach (PP6); and new camping areas (PP7). The coastal zone plans had greater importance in this context, not only due to the major transformations in beach equipment and parking areas but even in reorganizing uses and users; the PP1 also incorporated works of coastal protection. Environmental preservation and coastal safety were the two main concerns in this detailed plan. Massive building construction damages the quality of the sand and shrinks the 
beaches; therefore, there was a need to invest in redesigning the beach profile, artificially feeding with sand and constructing breakwater bars. This intervention aimed to improve the quality of the built and natural environment of Costa de Caparica's centre and its beaches, providing new public spaces with added value, because environmental quality was considered when creating new green urban structures. Mobility was given special attention by creating circulation restrictions on private transportation (Figure 2).

\section{Planning for sustainability in the context of Polis Program proposals}

Although the Polis Program has provided significant changes in Costa de Caparica's reality, it lacks a global vision for this territory, especially in what regards economic activities' sustainability and the environment. Costa de Caparica's public spaces lack night programmes; they neither promote nocturnal activities nor do they adapt to these activities through specific equipment. Along with day uses associated with tourism

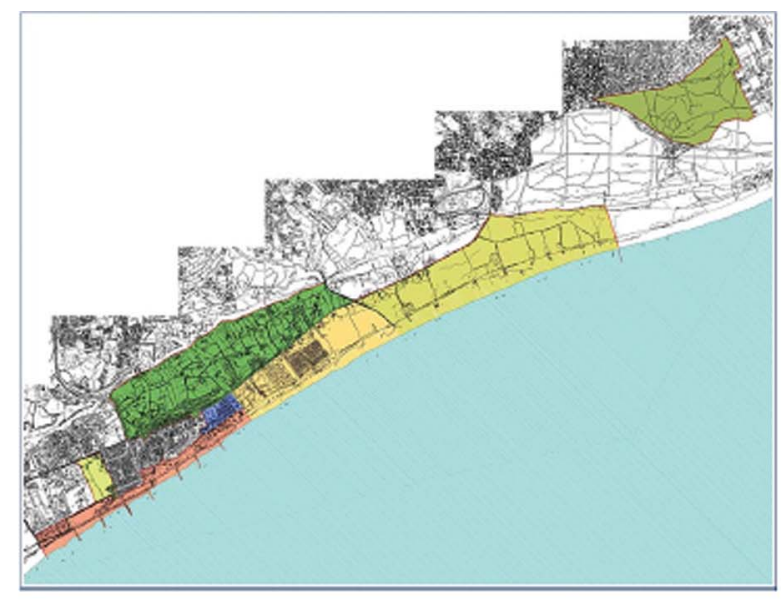

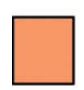

PP 1 - Urban beaches

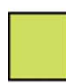

PP 2 - Urban garden

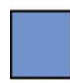

PP 3 - Campo da

Bola

PP 4 - Urban and rural

west front
PP 5 - Transition

beaches

PP 6 - Equipped

beach

PP 7 - New

camping areas

Figure 2. Intervention area of Costa de Caparica's Polis Program.

Source: Strategic plan of Costa de Caparica: living the city (2003), http://www.costapolis.pt/index.php. 
activities, such as beach and water sports, night uses such as restaurants, bars, discos, waterfronts promenade, stars observations and others were not taken into consideration by the master plan that intended to "develop actions that contribute to the re-development and revitalization of urban centres, and promotes the multi-functionality of those centres, strengthening their role in the region's context" (translated from Portuguese, Polis Program, www.costapolis.pt) (Almada Master Plan 1996). The regeneration work that partially focuses on the area's nightlife has targeted security issues. Parking areas along the beach corridor are excessively illuminated (Figure 3), as well as the waterfront walk (Figure 4) where bars and restaurants are not allowed to open during the night.

This article uses the "sustainable communities" characteristics of the Egan review (2004a) as an analytical framework for the analysis of Costa de Caparica's Polis Program.

Assuming that Costa de Caparica's development must assemble a sustainable community, the question "how can sustainable planning improve the nightlife of a specific waterfront district?" should be answered with the analysis of both the concluded plan for the Polis Program and sustainability components according to which a

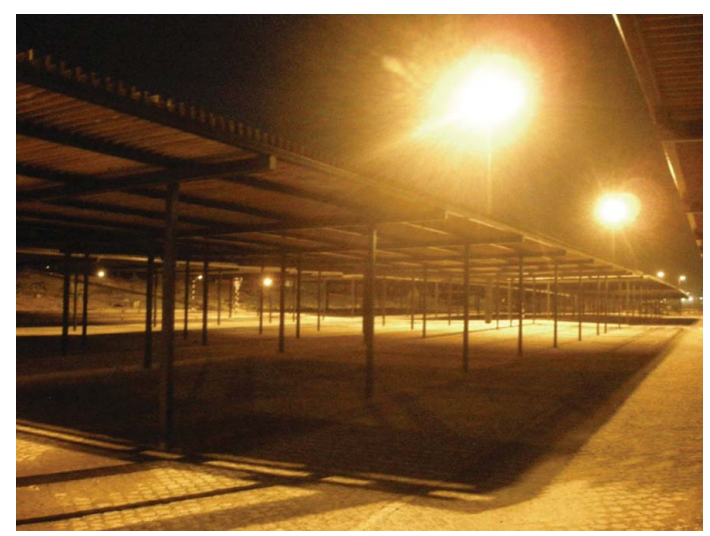

Figure 3. Perspectives of lightning in the parking area. Source: Photo by the author, April 2009. community should be based. In this view, this article uses the approach of the "sustainable communities" characteristics of the Egan review (2004a) as an analytical framework for the analysis of the Costa de Caparica Polis Program.

Through measuring activities, acts and territorial transformation, planning should guide communities to pursue the best for their inhabitants and to promote their life style as an example of good practice. Moreover, some measures must be addressed to accomplish the crossover between sustainability and nightlife. The Polis Program interventions brought to Costa de Caparica new places for public use, and so they could be used not only during daylight hours but also during the night, because conditions and equipment are already set. Table 1 presents the intention to gather diagnosed problems, Polis Program interventions and sustainable community's components of Egan's wheel and link them to achieve a balance between what is already done and what is desirable to improve the nightlife of Costa de Caparica.

The Polis Program brought several new approaches to urban planning and in a certain way it started new forms of diagnosing, decision and urban regeneration. After a troubled history of political decision-making and governmental changes (Baptista 2008), the programme

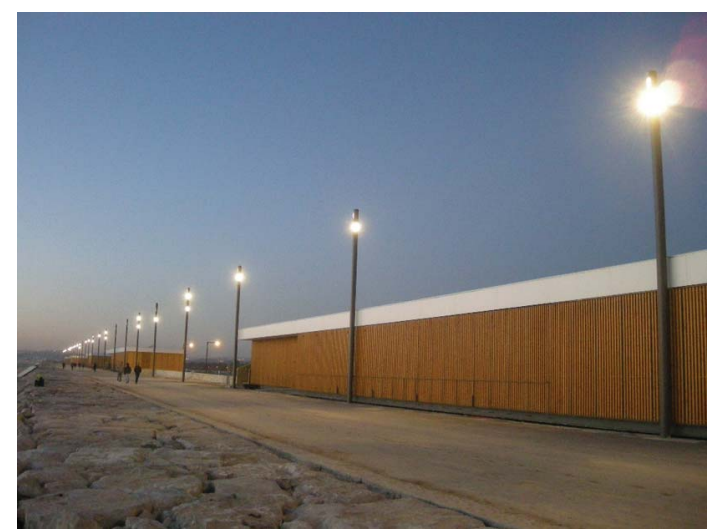

Figure 4. New equipment created by Polis Program and lightning devices along the waterfront.

Source: Photo by the author, April 2009. 
Table 1. Relation between Egan's components and proposed activities.

\begin{tabular}{|c|c|c|}
\hline Scope & Sustainability components & Proposals \\
\hline $\begin{array}{l}\text { The waste of energy connected } \\
\text { with lack of lighting planning } \\
\text { (Portela 2007) }\end{array}$ & Services/governance & $\begin{array}{l}\text { Energy cost associated with urban lighting } \\
\text { is a concern for local authorities, which } \\
\text { should programme suitable lighting for } \\
\text { different spaces and activities. Planners } \\
\text { should work with the community and } \\
\text { stakeholders to reach a fair use of public } \\
\text { space at night }\end{array}$ \\
\hline Planning process (Baptista 2008) & Equity & $\begin{array}{l}\text { To support and disclose public participation } \\
\text { initiatives would improve information } \\
\text { towards planning processes, mainly in } \\
\text { what regards to night uses and sustainable } \\
\text { practices around new intervention areas } \\
\text { (such as Polis Program) }\end{array}$ \\
\hline $\begin{array}{l}\text { Ecology and environment: } \\
\text { disturbances in maritime } \\
\text { ecosystems; light pollution } \\
\text { (Mizon 2002) }\end{array}$ & Environment & $\begin{array}{l}\text { The use of light sources that are directed to } \\
\text { the ground, guiding all their light below } \\
\text { and focus, specially on the waterfront } \\
\text { (Starlight Initiative 2007) }\end{array}$ \\
\hline $\begin{array}{l}\text { Lack of accessibility was } \\
\text { decreasing competitiveness and } \\
\text { urban space quality: traffic } \\
\text { congestion resulted from both } \\
\text { car use and the lack of suitable } \\
\text { public transportation use (Polis } \\
\text { Program 2003) }\end{array}$ & Transports and connectivity & $\begin{array}{l}\text { Reinforce networks and public transports to } \\
\text { respond to the seasonal increase of users } \\
\text { associated with beach pursuit: for } \\
\text { example, extend the Almada's surface } \\
\text { metro to Costa de Caparica; restructure } \\
\text { the schedules of the surface-tram along } \\
\text { the waterfront, including night use } \\
\text { because many bars and restaurants are } \\
\text { located within this line; reformulate the } \\
\text { existing "Transpraia" transportation }\end{array}$ \\
\hline Night space appropriation & Governance & $\begin{array}{l}\text { Improve lighting efficiency in the city } \\
\text { centre; promote regular meeting with } \\
\text { owners and police forces, diagnosing } \\
\text { critical events }\end{array}$ \\
\hline $\begin{array}{l}\text { Entertainment: bars and discos } \\
\text { are points of alcohol sale during } \\
\text { the night favouring delinquency } \\
\text { (Helms 2008) }\end{array}$ & Economy & Night security towards alcohol and crime \\
\hline $\begin{array}{l}\text { Standardization of the } \\
\text { waterfront's restaurants - } \\
\text { disrespect of cultural and } \\
\text { historical characteristics }\end{array}$ & House and built environment & $\begin{array}{l}\text { Lighting appealing: create light designs in } \\
\text { the entrance of the restaurants to } \\
\text { strategically differentiate them; for } \\
\text { example, discos cast a ray into the dark } \\
\text { sky to attract customers }\end{array}$ \\
\hline $\begin{array}{l}\text { Increasing demand for night } \\
\text { individual and collective uses } \\
\text { (Ascher 1997; Gwiazdzinski } \\
\text { 2003, 2005; Espinasse 2004; } \\
\text { Espinasse et al. 2005) }\end{array}$ & Social and cultural & $\begin{array}{l}\text { New public garden possesses football and } \\
\text { tennis fields, as well as running circuits } \\
\text { with illumination capable for night } \\
\text { sports; build a cultural equipment to } \\
\text { promote other night uses such as cinema, } \\
\text { theatres, exhibitions - complement to the } \\
\text { restaurants and bars that function as the } \\
\text { central piece in a strategy to eat, } \\
\text { see/participate and drink circuit that } \\
\text { could boost Costa de Caparica's night } \\
\text { economy (Alves 2010) }\end{array}$ \\
\hline
\end{tabular}


emerged as an opportunity for stagnated cities. It applied the high urban quality standards of the former EXPO'98 (World Exhibition) at its start. The EXPO'98 site was an old industrial and abandoned area of Lisbon transformed to be the place for the exhibition. Due to the good results, the city gained a fully regenerated area with architecture and public space design quality. This echoes the idea of the "disorderly country" maintained by Baptista (2008) whereby every municipality consequently wanted a small "EXPO" for marketing reasons. Real estate speculation has been strongly related with the planning practice in Portugal.

The success of EXPO'98 that inspired the Polis Program was based on four principles: (1) the urban regeneration works were completed in 5 years, which made decision-makers believe that in a smaller scale the execution time would shorten. Though sustainable communities take much longer to build, there is more than engineering works involved to build a community as Egan (2004b) has discussed in his eight components; (2) the creation of a public/private company responsible for the intervention's implementation and management (Parque Expo). Later, every Polis Program was assisted by Parque Expo and specific technical boards (Sociedade Polis) were created for the local implementation; (3) the top-down decisionmaking, in which the municipalities had no or little planning influence, eliminated several political decisions and alienated public participation of the planning process. In addition, governance was forgotten in this process, because leadership, representation and participation were made from the top, (4) resulting in public consultancy more than public participation. Much of the "participation" carried out by Costa de Caparica's Polis Program (among other Polis Programs) was based on public information sessions, where the management company (Sociedade Costa Polis) promoted public involvement in the decision-making process. However, this involvement was a part of the communication strategy, whereby the Polis Program and the mayor encouraged local residents to get involved in the sense of living in the new city transformed by Polis (Baptista 2008), and not public consultation throughout the planning process. In the context of Costa de Caparica, Sociedade Costa Polis promoted smaller meetings with key economic and local actors (fire corporation, municipal police, parish president, religious institutions, environmental activists, etc.), which approximated a form of public participation. However, these cannot be representative of all residents and users, whose interests also should have been respected. At this point, the equity component was missed in the process of achieving a sustainable community, because not everyone had the same opportunities to participate and had not benefited with the intervention's results.

Governance and equity are two components of Egan's wheel, highlighting the importance of the community-based decisions and also the inclusion of community's participation in the decision process. In addition, equity that amounts to fairness reminds the relevance of equal distribution of the various types of resources. These components, which should be strategic and integrate values and different perspectives, are major failures of Polis Program as a planning instrument. Partidário and Arts (2005) in her work about strategic methodological approaches presents key features of the strategic-based approach that should have been contemplated in the Polis Program, such as critical decision factors analysis, governance framework, communication strategy, discussion and assessment of the strategic options to select critical pathways for sustainability and problem perception, dialogues, development of trust and knowledge-brokerage among others. Equity and governance can be built based on these key aspects.

As was demonstrated, it is possible to cross Egan's sustainability components with the environmental and urban quality improvement of Polis Program goals, as also the night uses and economic activities of Costa de Caparica. A specific territorial ambition could be drawn in order to distinguish this from any other Polis intervention, which did not happen in the Costa de Caparica's Polis Program. 
Therefore, discussing whether planning for sustainability can improve the nightlife of a specific territory is to equate Costa de Caparica's nightlife existence and relevance in future plans and programmes. It is crucial to incorporate a diagnosis of night users, entrepreneurs and local authorities in what concerns crime and alcohol disturbances (Hobbs et al. 2003). This relation or predominance towards night economic activities must be identified and evaluated in order to understand their (un)sustainability and propose measures to solve specific problems, for example, crime and lack of lighting in public spaces (Roberts 2004). Additionally, reports of good practices should be produced in the Polis Program context to frame the intervention as a continuous improvement of something good existing before; Roberts' (2004) report assembles a literature review on the night economy subject, as well as recommendations based on individual night diagnoses and successful actions. This approach does not seem to be new; planners must know the night users, their practices and needs in order to innovate in urban night environments; they also need to evaluate natural threats and know about environmental potential of a place, for example, the scope and intensity of light pollution or the amount and direction of artificial lighting.

In general, the national Polis Program has had and continues to have positive impacts in the urban and environmental contexts, ordering the uses and structuring urban areas. Improving environmental and urban quality, restructuring mobility and innovating in urban design are specific and valuable goals from any socio-economic or geographical perspectives. However, two critiques stand out: one relates to a territorial intervention model broadly spread, resulting in a unique way of doing things, which ultimately compromises singularity and suitability; the other is the lack of a community-based approach to these plans (Polis Program) leading to a certain homogenization. Largely this standardization comes from the plan design itself, from the materials used to improve the built environment and also from the lack of public participation. The absence of public participation results not only due to the lack of participation mechanisms in the planning process but also deeply due to the mismatch between the plan phase and the point in time that people are called to participate. Public-participated planning should not come by the end of the planner's decision, but instead in the beginning of the plan scheme embodying a public understanding of what should be the intervention for their territory. The absence of public participation channels also creates a disarticulation among anticipated gains from the Polis Program and the set of activities that already existed, for example, the night economy services and the public space use (at night).

\section{Final remarks}

The Polis Program was an important planning initiative in Costa de Caparica, because this city was urgently in need of a full-scale intervention due to decades of explosive demographic growth, uncontrolled urban expansion and serious environmental conflicts. The main drivers of this planning intervention were accessibility and waterfront renewal, as well as the quality of public spaces. This has indeed produced a positive impact in Costa de Caparica's urban space quality; however, it has not addressed the main issues properly. Therefore, those specific architectural works have not produced a full-scale renewal effect, sidelining the city's capacity as a nightlife district. Night, as a space of socio-cultural and economic activities with a strong importance in the life of Costa de Caparica, was not addressed in the programme.

Regeneration policies must be modified and reframed in wider social, economic and cultural contexts, focusing on sustainable communities in aspects such as environmental sensitivity, connectivity, night services or urban design, which are important features that distinguish places and contributes to define place identity. This article provides academics and planners an insight into the approach of a specific planning instrument that apparently had an enormous success, but otherwise lacked strategy in night economy activities, users and practices, and likely many other urban 
interventions. More research is needed in bridging sustainability and night planning. Diagnoses, enquiries and stakeholder and community consultation are required to understand the night dimension of a place and how it can be planned equitably.

New visions are required to fit the Polis interventions at the local scale, especially concerning a framework analysis that highlights governance, public participation and equity, among other values inherent to planning. However, this change must come from the top - only profound changes in national policy can produce efforts to approach diverse communities in the planning process. Works like Egan's sustainable communities' components could help planners to establish guidelines for addressing public need and providing instruments to build up a better community.

\section{Notes on contributors}

Diana Neves Almeida: Centre for Geographical Studies, Institute of Geography and Spatial Planning, University of Lisbon, Ed.Fac.Letras, Alameda da Universidade, Lisbon 1600-214, Portugal

João Mota-Guedes Fumega: Centre for Geographical Studies, Institute of Geography and Spatial Planning, University of Lisbon, Ed.Fac.Letras, Alameda da Universidade, Lisbon 1600-214, Portugal

\section{References}

Almada Master Plan. 1996. Plano Director Municipal e de identificaçãi dos principais factores de evolução do municí́pio. Rev. 2008. Almada (Portugal): Ed. Direcção municiapl de planeamento e administração do território.

Alves T. 2007. A noite, a cidade e a geografia das actividades económicas, Geophilia. O sentir e os sentidos da Geografia. In: Homenagem a Jorge Gaspar, editor. Lisboa (Portugal): Centro de Estudos Geográficos. p. $498-500$.

Alves T. 2009. Fazer Geografia através da Luz. Lisboa (Portugal): Centro de Estudos Geográficos, Universidade de Lisboa.

Alves T. 2010. Geografia da Noite, conhecer, compreender e repensar os territórios (programa). Lisboa (Portugal): Research Group of TERRiUTR, Centro de Estudos Geográficos.
Ascher F. 1997. Du vivre en juste à temps au chronourbanisme. Les Annales de la Recherche Urbaine. 77:113-122.

Baptista I. 2008. O Programa POLIS e o "País Desordenado": percepções sobre governância e planeamento urbano em Portugal. In: Cabral MV, Silva FC, Saraiva T, editors. Cidade e Cidadania: Governança urbana e participação cidadã em perspectiva comparada. Lisboa (Portugal): Instituto de Ciências Sociais. p. 1-34.

Cauquelin A. 1977. La ville la nuit. Paris (France): PUF.

Deleuil JM. 1994. Lyon La Nuit, lieux, pratiques et images. Lyon (France): Transversales Presses Universitaires de Lyon.

Egan J. 2004a. The Egan review: skills for sustainable communities. London (UK): Crown.

Egan J. 2004b. Skills for sustainable communities. London (UK): Office of the Deputy Prime Minister.

Egan J. 2004c. Egan's wheel for sustainable communities [Internet]. [cited 2012 Jan 4]. Available from: http://www.geography.org.uk/projects/buildingsustai nablecommunities/onlinecpdunit/stimulus/activity1/.

Espinasse C, Buhagiar P. 2004. Les passagers de la nuit. Vie nocturne des jeunes. Paris (France): Editions L'Harmattan.

Espinasse C, Gwiazdzinski L, Heurgon E, coord. 2005. La Nuit en question(s). Vaucluse (France): Colloque de Cerisy, Editions L'aube essai.

Gwiazdzinski L. 2003. La ville 24 heures sur 24. La Tour-d'Aigues (France): Editions l'Aube.

Gwiazdzinski L. 2005. La Nuit, derniére frontiére de la ville. La Tour-d'Aigues (France): Editions 1'Aube.

Helms G. 2008. Towards safe city centres? Remaking the spaces of an Old-Industrial City. Hampshire (UK): Ashgate.

Hobbs D, Hadfield P, Lister S, Winlow S. 2003. Bouncers: violence and governance in the nighttime economy. Oxford (UK): Oxford University Press.

Hollands R, Chatterton P. 2003. Producing nightlife in the new urban entertainment economy: corporatisation, branding and market segmentation. Int J Urban Reg Res. 27(2):361-385.

House and Communities Academy [Internet]; [cited $2011 \mathrm{Feb}$. Available from: www.hcaacademy.co.uk

Instituo Nacional de Estadística. 2001. Censos 2001: XIV recenseamento geral da população [Internet]. [cited 2009 Apr 14]. Available from: www.ine.pt

Instituto de Astrofisica de Canarias. 1992. Sky Law No. 243/1992. Canarias (Spain): Light Pollution and Regulation Office.

Law No. 26/2000. 2000. Polis Program creation, Diário da República I Série, No.112th, 15/05/2000. 
Mizon B. 2002. Light pollution: responses and remedies. London (UK): Springer.

Narboni R. 2003. Brève histoire de l'urbanisme lumière In Penser la ville par la lumière. Paris (France): Project Urbain, Éditions de la Villette.

Ostrom E. 1993. Social capital and development projects. Prepared for social capital and economic development. American Academy of Arts and Sciences, Cambridge, MA, 30-31 Jul.

Pain R, Smith SJ, editors. 2008. Fear: critical geopolitics and everyday life, collection Rematerialising Cultural Geography. Hampshire (UK): Ashgate.

Paquot T. 2000. Le sentiment de la nuit urbaine aux XIX et XX siècles. Les Annales de la Recherche Urbaine. 87:6-14.

Partidário MR, Arts J. 2005. Exploring the concept of strategic environmental assessment follow-up. IAPA. 23(3): 246-257.

Polis Program. 2003. Strategic plan of Costa de Caparica: living the city [Internet]. Lisbon (Portugal): Ministry of Environment and Territorial Planning; [cited 2011 Jan 19]. Available from: http:// www.costapolis.pt/index.php
Portela C. 2007. Light and architecture, conference StarLight: a common heritage, Starlight Initiative. Tenerife (Spain): Instituto de Astrofísica de Canarias (IAC). p. 111-114.

Ribeiro JMF. 1999. Programa de Requalificação Urbana e Valorização Ambiental das Cidades. Lisboa (Portugal): Ministério do Ambiente e do Ordenamento do Território.

Roberts M. 2004. Good practice in managing the evening and late night economy: a literature review from an environmental perspective, Central Cities Institute, University of Westminster. London (UK): Office of the Deputy Prime Minister.

Roseland M. 2005. Toward sustainable communitiesrevised edition. Gabriola (BC): New Society Publishers.

Starlight Initiative. 2007. International initiative in defence of the quality of the night sky as Mankind's scientific, cultural and environmental right [Internet]. [cited 2009 Mar 20]. Available from: http://www.starlight2007.net/videoeng.htm

Talbot D. 2007. Regulating the night. Culture and exclusion in the making of the night-time economy, Hampshire (UK): Ashgate. 